\title{
Gender, Organizational Commitment and Job Performance in the Ugandan Local Government
}

\author{
Leonsio Matagi $^{1 *} \quad$ Peter Baguma $^{1} \quad$ Murindwa Rutanga $^{2} \quad$ Martin Baluku $^{1}$ \\ 1.School of Psychology, Makerere University, P. O. Box 7062, Kampala, Uganda \\ 2.School of Social Sciences, Makerere University, P. O. Box 7062, Kampala, Uganda
}

\begin{abstract}
The purpose of this paper was to establish the association between gender, organizational commitment and job performance of sub-county chiefs in the Ugandan local government. Most of the literature review indicates the effect of gender on organizational commitment, the effect of gender on job performance and the relationship between organizational commitment and job performance. A total of 320 sub-county chiefs were involved in the study and were selected using multi-stage stratified random sampling. A self-administered questionnaire used to collect data measured the following variables: Organizational commitment, job performance, and demographic variables of gender, age, educational level and tenure (years of experience). Data was entered into the computer using SPSS program. Factor analysis was carried out to establish different components of job performance, which were: cooperation, time consciousness, organization citizenship behavior (OCB), and communication. The already established components of organizational commitment that were used were: affective, continuance and normative commitment. A t-test, Pearson correlation and regression analyses were carried out to test the hypotheses. Results indicated that: gender does not significantly influence organizational commitment as well as it components of affective, continuance and normative commitment; males and females do not significantly differ on their levels of job performance and its components of cooperation, time consciousness, organization citizenship behavior and communication; there was a positive significant relationship between overall job performance and affective commitment as well as normative commitment; and only affective commitment was a significant predictor of job performance. Employees who value hard work, and are committed and highly participate in organizational activities are likely to be outstanding (good) performers. However, targeting one employee attitude in order to improve performance may not be enough. It is very important to focus on a combined pattern of work attitudes to obtain the desired goals.
\end{abstract}

Keywords: Gender, Organizational commitment, Job performance

DOI: $10.7176 / \mathrm{EJBM} / 12-14-03$

Publication date:May $31^{\text {st }} 2020$

\section{Introduction}

The job model suggests that when women perform in the same organizational settings as their male counterparts, their attitudes are shaped by the same factors, and that there should be no significant differences across the two groups (Dodd-McCue \& Wright, 1996). The model suggests that workplace experiences determine attitudinal commitment. From a gender model perspective on the other hand, it is contended that gender-related differences in job attitudes represent true psychological differences resulting from early socialization of males and females (Rosener, 1990), and by socially determined gender roles (Eagly, Wood, \& Diekman, 2000). The gender model contends that socialization shapes attitudinal commitment. However, even though many studies have found no differences in job attitudes by gender (e.g. Aven, Parker, \& McEvoy, 1993; Smith, Smits, \& Hoy, 1998), and that women may even be more committed than men to their work and careers, among other job attitudes (e.g. Mathieu \& Zajac, 1990; Wahn, 1998), there are perceptions that men and women have different job attitudes (Schwartz, 1989) and some empirical studies have reported such attitudinal differences (Kaldenberg, Becker, \& Zvonkovic, 1995). More support of the gender model includes the following empirical studies: that significant and fundamental differences exist between genders (Gray, 1992); several statistics indicate gender disparities among CEOs, parliamentarians, nonprofit organizations, and men being higher than women (Sandberg, 2013); that gender disparities are not decreasing and persist over time (Slaughter, 2015); and that gender disparities exist among medical school department chairs (Kolovich, 2015).

The most commonly cited definition of organizational commitment is that of Mowday, Porter and Steers (1982). They defined it as the relative strength of an individual's identification with and involvement in a particular organization. As Meyer and Allen (1991) outlined, commitment consists of three dimensions, namely, affective, continuance and normative commitment. Affective organizational commitment is defined as the relative strength of an individual's identification with and commitment to an organization. Three aspects characterize affective commitment: a strong belief in and the acceptance of organizational goals and values, the willingness to exert considerable effort on behalf of the organization, and a strong desire to maintain membership in the organization (Dipboye, Smith, \& Howell, 1994; McCaul, Hinsz, \& McCaul, 1995).

Continuance commitment refers to the commitment employees experience towards the organization because 
of investments they have made or because of the costs associated with leaving the organization (Mathieu \& Zajac, 1990; Dipboye et al., 1994). This form of commitment develops when employees realize that they have accumulated investments they would lose if they left the organization or because their alternatives are limited. The difference between affective commitment and continuance commitment is that employees high in affective commitment stay with the organization because they want to, while employees high in continuance commitment stay because they have to (Meyer, Allen, \& Gellatly, 1990).

Meyer and Allen (1991) identified a third dimension of organizational commitment, which they describe as normative commitment. This form of commitment concerns a feeling of (moral) obligation to remain in the organization. What these three dimensions have in common is that they all indicate the extent to which employees are willing to remain in an organization.

Individual job performance is the measure of the degree to which a job is done well by the employee. Effective performance of a job is the attainment of specific results (i.e., outcomes) required by the job through specific actions while maintaining or being consistent with policies, procedures, and conditions of the organizational environment (Boyatzis, 1982). According to Sackett (2002), eight job performance facets/components include: job-specific task proficiency, non-job specific task proficiency, written and oral communication, demonstrating effort, maintaining personal discipline, facilitating peer and team performance, supervision/leadership, and management/ administration. Standard performance is the average output which is achieved by an experienced employee.

\section{Literature Review}

\subsection{Gender and organizational commitment}

One of the most popular demographic variables in commitment studies is gender. However, gender and organizational commitment research has produced inconsistent results. Several researchers state that men are more committed to the organization than women (Dodd-McCue \& Wright, 1996; Al-Ahmadi, 2009); others do not find gender differences (Matsiko, 2005; Matagi, 2006; Dick \& Metcalfe, 2007; El Badawy, Chinta, \& Magdy, 2018). Contrary to these results, Marchiori and Henkin (2004), Singh, Finn and Goulet (2004), and Dixon, Cunningham, Sagas, Turner and Kent (2005) have found that women have significantly higher levels of organizational commitment than men.

Wahn's (1998) study among human resource executives found that women showed a higher continuance commitment than men, whereas Ngo and Tsang (1998) found no significant relationship between gender and commitment. Further, a meta-analytic study by Mathieu and Zajac (1990) found that women are more affectively committed to the organization than men. In the study of gender and continuance commitment, Wahn (1998) suggests that women may have higher organizational commitment because they perceive fewer job alternatives than their male counterparts. That is, if women believe that they have fewer opportunities for employment in other organizations, they will have higher levels of commitment to their current organizations than do men.

Organizational commitment was found to be higher among men than women in four countries (Australia, China, Hungary, Jamaica) and higher among women than men in two countries (Bulgaria and Romania) (Peterson et al. 2019). Gender and years of experience were significant predictors of organizational commitment components of identification and internalization (Sezgin, 2009). Singh et al. (2004) found out that gender was significantly and positively related with overall organizational commitment, but not with continuance commitment. In a similar study, respondents' gender revealed no significant relationship with employees' affective commitment, a weak relationship with normative commitment and overall organizational commitment and a significant negative relationship with continuance commitment (Suliman \& Iles, 2000).

Namasivayam and Zhao (2007) found out that gender was not significantly related with all components of organizational commitment, that is, affective, normative and continuance commitment. Similarly, Labatmediene, Endriulaitiene and Gustainiene (2007) found no main effect of gender on organizational commitment, that is, there was no significant gender difference in overall organizational commitment, continuance commitment, and normative commitment. Like Carriere and Bourque (2009), they still noted a statistical tendency of differences (not significant) in affective commitment between men and women. Similar findings in respect to affective and continuance commitment had been obtained by Joiner and Bakalis (2006), and by Carmeli (2005) in respect to affective and normative commitment. Other similar studies confirmed that there was no association of significance between gender and organizational commitment (Fogarty, 1996; Metcalfe and Dick, 2002; Matagi, 2006; Dick \& Metcalfe, 2007; Popoola \& Oluwole, 2007; Kuruuzum et al., 2009; Kim, Lee \& Kim, 2015).

H1: Females than males will indicate significantly higher levels of overall organizational commitment and its components. 


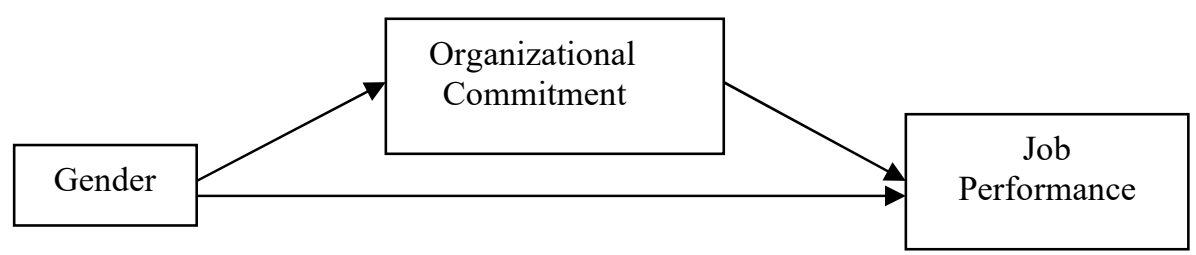

Figure 1: The Research Conceptual Framework of the study

\subsection{Gender and performance}

Some research findings indicate gender differences, and others indicate none in as far as the performances of men and women are concerned. One body of research maintains that there are no significant differences in the behaviors (e.g. performance ratings) of male and female leaders (Vilkinas \& Cartan, 1993; Fogarty, 1996; Kim, Lee \& Kim, 2015), and in the overall emotional intelligence of men and women (Petrides \& Furnham, 2006). Additional studies report that women and men in leadership roles are more similar than different (Lyness \& Thompson, 1997). Perceived discrepancies in the attributes of men and women were found to diminish when women were designated as successful (Heilman, Block and Martell, 1995). Recently, Arinaitwe (2005), Gava (2005), Matsiko (2005), Suliman (2007), Hailesilasie (2009), Rodríguez-Ruiz et al (2016), and Solakoglu and Demir (2016 found out that gender showed no significant relationships with performance.

Similar studies provide empirical evidence that men and women do not perform differently in managing their entrepreneurial businesses and that their managerial performance and attitudes correspond in many aspects (Menzies, Diochon, \& Gasse, 2004; Orser \& Riding, 2004), while a third group of studies addresses the advantages women have in specific functions in management. The body of studies focusing on the managerial performance for which women are at an advantage compared to men includes managerial functions related to people; women more than men focus on their teams' development, empower their subordinates and encourage their workers' achievements and perseverance (Bruni, Gherardi, \& Poggio, 2004; Brush, Carter, Gatewood, Greene, \& Hart, 2004). Other studies report that women entrepreneurs spend more time in networking, more engaged in conducting market research and typically demonstrate advantages in strategic planning, leading change (Morris, Miyasaki, Watters, \& Coombes, 2006; Walker \& Webster, 2006) and innovation (Sexton \& Bowman-Upton, 1990; Goldsmith, Freiden, \& Eastman, 1995).

A contrasting body of research finds that there are gender differences in leadership behaviors. Women leaders have been reported to have better people skills than men (Rutherford, 2001), to be more visionary (Vinnicombe, 1987), to have a more democratic leadership style (Eagly \& Johnson, 1990) and a more transformational style relying on consideration and interpersonal skills (Bass \& Aviolo, 1997; Eagly \& Johannesen-Schmidt, 2001). Perrault and Irwin's (1996) study of men and women at the executive levels in a variety of companies found that women outperform men in 28 of 31 skill areas, leading them to conclude that women behave similarly but more effectively than their male colleagues. Similar results were reported by Sharpe (2000), i.e. women executives received higher ratings on 42 of 52 skills measured, and Shore (1992), i.e. women were rated significantly higher than men on six of seven performance dimensions.

A sizeable body of research has discovered that there are indeed differences in the assessments of female leaders and of male leaders. One line of reasoning cited for these gender differences has been a "think manager, think male" stereotypical view of leadership (Metcalfe \& Altman, 2001). Brenner, Tomkiewicz and Schein (1989) discovered that both women and men saw successful leaders as male. Many leadership skills are observed through gender stereotypes and regarded differently when performed by men or by women (Martell \& DeSmet, 2001; Merrill-Sands \& Kolb, 2001).

Another major finding that repeatedly emerges from studies on entrepreneurship is that women-owned businesses and men-owned businesses, respectively, differ in some success measures (Alsos, Isaksen, \& Ljunggren, 2006; Grilo \& Irigoyen, 2006). With the exception of a few recent studies showing no gender differences among entrepreneurial businesses in some success measures (Menzies et al., 2004; Johnsen \& McMahon, 2005), most studies revealed differences in business longevity (Low \& MacMillan, 1988), rates of sales (Cassar, 2004; Covin, Green, \& Slevin, 2006), and rates of growth (Bhide, 2000; Watson, 2006) among others. Previous studies on entrepreneurship have shown that men and women differ in their managerial skills and performance (Perry, 2002; Morris et al., 2006). Most of these studies have shown that women entrepreneurs are less successful in turning their managerial performance into successful and profitable enterprises (e.g. Du Reitz \& Henrekson, 2000). But Dafna (2008) indicated that women entrepreneurs however, both Canadian and Israeli, ranked significantly higher in some functions of their managerial performance compared to their male counterparts.

Recent studies have also indicated a similar mixed trend. To obtain an overall picture of self-rated performance according to personal characteristics, results indicated that self-reported performance was significantly higher among male than female respondents (Crossman \& Abou-Zaki, 2003; Al-Ahmadi, 2009). In 
another study, male leaders were assessed as more successful even when the male and female leaders demonstrated an equivalent level of competences (Hopkins \& Bilimoria, 2008). However, Millmore, Biggs and Morse (2007) did research using 66 managers (33 males and 33 females) against four broad capabilities on the 360-degree appraisal system. Like Maamari and Saheb (2018), their results illustrated that females had an overall higher performance rating score than males. This difference was found to be statistically significant. This result indicates that females were rated significantly higher than males in the overall scores achieved on the 360-degree appraisal system. Taken at face value, this may reflect that female managers were consistently out performing their male counterparts on the work-related competences assessed and that this has been objectively identified through the 360-degree appraisal process.

Millmore et al. (2007) gave an explanation for the superior performance by female managers. One possible explanation relates back to the suggestion that female managers have something more to prove than male managers and, as a result, may work harder or differently to achieve results (Greener, 2007). If this is the case, then at least their efforts are being recognized through the 360-degree appraisal system in the case company (Fletcher, 1999). An alternative explanation is provided by the "gender contrast" effect (Heilman, et al., 1988), where the overrating of females performing roles perceived as male-oriented, such as management, is evidenced. The argument here is that raters are surprised by the actual performance of females in comparison to sex-based stereotypes, particularly, given the perceived barriers that they need to surmount if they are to succeed, leading to overcompensation in any ratings of performance.

H2: Females than males will indicate significantly higher levels of overall job performance and its components.

\subsection{Organizational commitment and performance}

Organizational commitment has been an important research topic having both practical and theoretical implications. Organizations are intended to have more highly committed workforce, because several research results show that organizational commitment leads to important outcomes such as decreased turnover, higher motivation, higher organization citizenship behavior and organizational support (e.g. Kwon \& Banks, 2004). The concept of "organizational commitment" has gained increasing attention primarily because of its negative relationship between absenteeism and employee turnover (Kuruuzum et al., 2009). Greater organizational commitment has been linked to low rates of absenteeism and also better job performance (Cohen, 1992; Khatri \& Fern, 2001; Subramaniam et al., 2002). Interest in the relationship between organizational commitment and performance is based on the assumption that employees who feel attached to, and identify with their organizations, are more likely to work harder.

Tang et al. (2000), Suliman (2002) and Tumwebaze (2009) found out that job performance was positively and significantly correlated with organizational commitment, which was also found to be a strong predictor of employees' performance (Al-Ahmadi, 2009). Looking at the differences between employees either in managerial or full time accounting positions and between respondents, Chen, Silverthorne and Hung (2006) found that organizational commitment and performance were positively and significantly related. Liu (2009) also found a significant positive relationship between affective commitment and organizational directed organizational citizenship behavior. Recent research also indicates that diversity management and organizational commitment were positively related to in-role performance (Kim, Lee \& Kim, 2015). Organizational commitment and employee performance have been found to be significantly related (Hendri, 2019; Nasab and Afshari, 2019). This research suggested that affective, continuance and normative commitment all had significant and positive association with individual job performance (Al Zefeiti and Mohamad, 2017; Torlak et al, 2018). According to Rukh et al. (2018), organizational commitment is associated with employees' positive behavior. Committed employees to the organization tend to willingly exert high levels of effort in achieving organizational goals and as a result contribute to positive organizational outcomes (Afshari and Gibson, 2016). Similar findings had been obtained by Ward and Davis (1995), Suliman and Iles (2000), Yousef (2000), Gava (2005), Sande (2005), Suliman and Kathairi (2013), and Indarti et al (2017).

Some other researchers found a relationship between job performance and commitment. However, they concluded that the direction of the relationship depended on the type of commitment. Job performance was found to have a strong positive relationship with affective commitment (Meyer et al., 1989; Meyer \& Allen, 1997; Suliman \& Iles, 2000; Suliman, 2002; Luchak \& Gellatly, 2007), and normative commitment (Meyer \& Allen, 1997; Suliman \& Iles, 2000), while a negative relationship was found between continuance commitment and performance (Meyer et al. 1989). Mathieu and Zajac (1990) found low positive correlation between organizational commitment and performance, which lead to the belief that there are other variables that moderate this relationship. Similarly, Samad (2005) found a moderate positive relationship between organizational commitment and job performance, and concluded that job satisfaction moderates the relationship between organizational commitment and job performance, indicating that employees, who are committed to their organizations, would have better job performance if they were satisfied in their jobs.

On the other hand, few researchers have found no significant relationships between commitment and 
performance. Organizational commitment was found to be significantly associated with job satisfaction, but not with employee performance (Yiing \& Ahmad, 2009). Carmeli and Freund (2004) examined the relationships between joint work commitments, job satisfaction, and job performance of lawyers employed by private law firms in Israel and found out that performance was significantly related to career commitment, but not to affective and continuance commitments. Continuance commitment tends to be unrelated or negatively correlated to work behaviors such as attendance, job performance and organizational citizenship behavior (Meyer et al., 1989; Angle \& Lawson, 1994; Meyer et al., 2002; Suliman, 2002). Other results also suggest that organizational commitment does not affect performance in a very significant way (Pinho et al, 2014), and that a very weak relationship was found between organizational commitment and organizational performance.

However, a common agreement is that a highly committed employee would contribute more to the performance of the organization than the less committed one (Suliman, 2002; Freund \& Carmeli, 2003). The rationale is that commitment to work, career, job and organization would enhance the desire to stay and develop within the organization (Vandenberg \& Scarpello, 1994), and this partly explains the reason why Suliman and Iles (2000), unlike some other studies (e.g. Sethivikram, Meinert, Kingrking, \& Sethiavsethi, 1996; Caruana, Ewing, \& Ramaseshan, 1997) found a significant positive relationship between continuance commitment and job performance. Organizational commitment contributes to better performance, as more committed employees should be more motivated to work hard on their organization's behalf (Suliman, 2002).

H3: There is a significant positive relationship between organizational commitment and job performance. H4: Organizational commitment components of affective, continuance and normative commitment will significantly predict job performance.

\section{Methodology}

3.1 Sample

A total of 320 sub-county chiefs who were involved in the study were selected using multi-stage stratified random sampling. Males were $79.1 \%$ as compared to females at $20.9 \%$; with an average age of 34 years; and majority being degree holders $(72 \%)$.

\subsection{Measures}

A self-administered questionnaire was used to collect data. It measured the following variables:

Organizational commitment: The study used 16 items of affective commitment. The first set of 9 items were developed by Mowday, Steers and Porter (1979), and used by Yousef (2001), who obtained a reliability coefficient of 0.82 , and also used by Yilmaz (2002) who obtained a reliability coefficient of 0.92 . The second set of 7 items of affective commitment were developed by Allen and Meyer (1990), and used by Carmeli and Freund (2004) who obtained a reliability coefficient of 0.86 , and also used by Kuruzuum et al. (2009) who obtained an $\alpha$ of 0.70 . The study also used 12 items of continuance commitment. The first 4 items were developed by Hunt, Chonko and Wood (1985), and used by Yilmaz (2002) who obtained a reliability coefficient of 0.88 , with extracted variance of 0.66 . The second set of 8 items of continuance commitment were developed by Allen and Meyer (1990), and used by Carmeli and Freund (2004), who obtained a reliability coefficient of 0.81 , and also used by Kuruzuum et al. (2009), who obtained a reliability coefficient of 0.76 . The 8 items of normative commitment used were developed by Allen and Meyer (1990), and used by Carmeli (2005), who obtained a reliability coefficient of 0.63 , and also used by Kuruzuum et al. (2009), who obtained a reliability coefficient of 0.78 . All responses were precoded as I strongly disagree (scored as 1) through I strongly agree (scored as 7).

Performance: A total of 30 items used were developed from the results of the modified repertory grid (which was part of the competence profiling phase). Responses were pre-coded as never (scored as 0) through always (scored as 4).

Demographic variables: Gender was measured as a separate demographic variable, with two levels of male and female (scored as 1 and 2 respectively). Other variables were: age in years categorized as: below 25, 25-29, 30-34, 35-39, 40-44, 45-49, and 50 and above (scored as 1 through 7 respectively); educational level categorized as: O-level, A-level, Diploma, Degree, Masters, PhD (scored as 1 through 6 respectively); and tenure (years of experience) was recorded as given.

\subsection{Analysis and results}

Data was entered into the computer using SPSS program. Factor analysis was carried out to establish different components of job performance, which were: cooperation, time consciousness, organization citizenship behavior (OCB), and communication. The already established components of organizational commitment that were used were: affective, continuance and normative commitment. Apart from the demographic variables, a total score for each sub-scale was computed to be used in hypothesis testing. A high total score indicated a high value of the attribute being measured, and vice versa. A t-test, Pearson correlation and regression analyses were carried out to test the hypotheses. 
According to the t-test results, gender does not significantly influence organizational commitment $(\mathrm{t}=.611$; $\mathrm{p}>.05)$, as well as it components of affective $(\mathrm{t}=-.452 ; \mathrm{p}>.05)$, continuance $(\mathrm{t}=1.221 ; \mathrm{p}>.05)$ and normative $(\mathrm{t}=.791$; $\mathrm{p}>.05$ ) commitment (Table 1). H1 was not supported. In the same way, H2 was also not supported (Table 2). Males and females do not significantly differ on their levels of job performance $(\mathrm{t}=.892 ; \mathrm{p}>.05)$ and its components of cooperation $(\mathrm{t}=1.632 ; \mathrm{p}>.05)$, time consciousness $(\mathrm{t}=.483 ; \mathrm{p}>.05)$, organization citizenship behavior $(\mathrm{t}=-.144$; $\mathrm{p}>.05)$ and communication $(\mathrm{t}=-.1 .301 ; \mathrm{p}>.05)$.

Table 1: t-test results of gender and organizational commitment.

\begin{tabular}{llrrrrr}
\hline Dependent variables & Gender & \multicolumn{1}{c}{ N } & Means & \multicolumn{1}{c}{ S } & t & $\boldsymbol{p}$ \\
\hline Affective Commitment & Male & 203 & 78.53 & 13.93 & -.452 & .652 \\
Continuance Commitment & Female & 47 & 79.53 & 12.84 & & \\
& Male & 204 & 47.25 & 8.99 & 1.221 & .223 \\
Normative Commitment & Female & 51 & 45.55 & 8.38 & & \\
& Male & 219 & 33.77 & 6.60 & .791 & .430 \\
Organizational Commitment & Female & 53 & 32.98 & 6.22 & \multirow{2}{*}{.511} & .542 \\
& Male & 159 & 159.64 & 22.25 & .61 \\
& Female & 34 & 157.12 & 19.91 & & \\
\hline
\end{tabular}

Table 2: t-test results of gender and job performance.

\begin{tabular}{llrrrrr}
\hline Dependent variables & Gender & N & Means & \multicolumn{1}{c}{ S } & t & $\boldsymbol{p}$ \\
\hline Cooperation & Male & 203 & 25.76 & 6.42 & 1.632 & .104 \\
Time Consciousness & Female & 55 & 24.13 & 7.21 & & \\
& Male & 236 & 20.02 & 2.76 & .483 & .630 \\
Organization Citizenship Behavior & Female & 57 & 19.82 & 2.77 & & \\
& Male & 232 & 17.12 & 3.69 & -.144 & .885 \\
Communication & Female & 61 & 17.20 & 3.56 & & \\
& Male & 245 & 20.83 & 2.45 & -1.301 & .194 \\
Job Performance & Female & 57 & 21.28 & 2.32 & \\
& Male & 182 & 83.82 & 9.79 & .892 & .373 \\
\hline
\end{tabular}

Correlation results indicate a positive significant relationship between overall organizational commitment and overall job performance $(\mathrm{r}=.282 ; \mathrm{p}<.01)$. H3 is supported. Apart from continuance commitment, there was a positive significant relationship between overall job performance and: affective commitment $(\mathrm{r}=.316 ; \mathrm{p}<.001)$, and normative commitment $(\mathrm{r}=.159 ; \mathrm{p}<.05)$.

\section{Table 3: Correlation results}

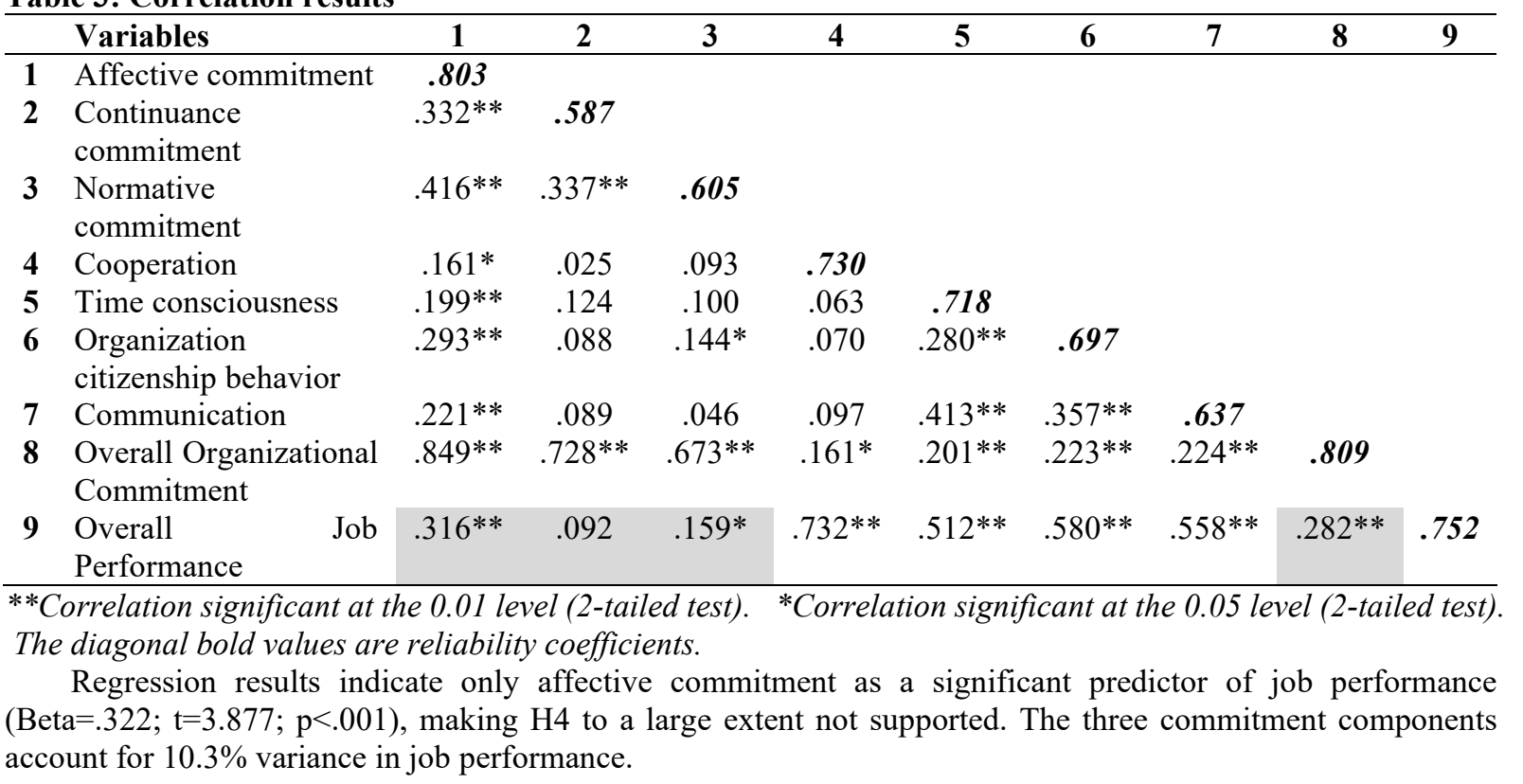


Table 4: Regression results

\begin{tabular}{lccccccc}
\hline Model & \multicolumn{2}{c}{$\begin{array}{c}\text { Unstandardized } \\
\text { Coefficients }\end{array}$} & $\begin{array}{c}\text { Standardized } \\
\text { Coefficients }\end{array}$ & t & Sig. & $\begin{array}{c}\text { Adjusted } \\
\text { R Square }\end{array}$ \\
\cline { 2 - 6 } & B & Std. Error & Beta & & & \\
\hline (Constant) & 63.506 & 5.241 & & 12.117 & .000 & \\
Affective Commitment & .242 & .062 & .322 & 3.877 & .000 & .103 \\
Continuance Commitment & -.078 & .086 & -.075 & -.914 & .362 & \\
Normative Commitment & .147 & .122 & .099 & 1.202 & .231 & \\
\hline
\end{tabular}

Dependent Variable: Job Performance

\section{Discussion \\ 4.1 Gender and Organizational Commitment}

The job model explains why male and female employees may not differ in their work attitudes, and probably in their work outcomes. It suggests that when women work in the same organizational settings as their male counterparts, their attitudes are shaped by the same factors and that there should be no significant differences across the two groups (Dodd-McCue \& Wright, 1996). Findings from previous researchers on gender-attitudes relationships are mixed. Some are in line with the study findings and concur with the job model. When sex and commitment are considered, some researchers did not find gender differences in overall job commitment (Matsiko, 2005; Matagi, 2006; Dick \& Metcalfe, 2007; Kuruuzum et al., 2009; Kim, Lee \& Kim, 2015). In similar studies, respondents' gender revealed no significant relationship with employees' affective commitment (Suliman \& Iles, 2000; Carmeli, 2005; Joiner \& Bakalis, 2006; Carriere \& Bourque, 2009). In addition, Labatmediene et al. (2007) and Namasivayam and Zhao (2007) found out that gender was not significantly related to all components of organizational commitment, that is, affective, normative and continuance commitment.

However, some previous findings are not in line with the study findings and concur with the gender model. From a gender model perspective, it is contended that gender-related differences in job attitudes represent true psychological differences resulting from early socialization of males and females (Rosener, 1990), and by socially determined gender roles (Eagly et al., 2000). Whereas several researchers state that men are more committed to the organization than women (e.g. Al-Ahmadi, 2009), others have found that women have significantly higher levels of organizational commitment than men (Marchiori \& Henkin, 2004; Singh et al., 2004; Dixon et al., 2005). In addition, Mathieu and Zajac (1990) found that women were more affectively committed to the organization than men, and Wahn's (1998) study among human resource executives found that women showed a higher continuance commitment than men. It is suggested that women may have higher organizational commitment because they perceive fewer job alternatives than their male counterparts. That is, if women believe that they have fewer opportunities for employment in other organizations, they will have higher levels of commitment to their current organizations than do men.

Though the research findings agree with the job model, most previous researchers support the gender model. There is therefore a strong support for the notion that men and women have different job attitudes and this may influence their work outcomes.

\subsection{Gender and Job Performance}

The finding on 'gender-performance' relationship is in agreement with the job model, that is, males and females who work in the same organizational setting don't differ in their attitudes and possibly work outcomes. This should not have been the case for this study because the respondents (sub-county chiefs) work in different sub-counties which are different in many aspects. May be the few similarities between these sub-counties should have influenced such a trend.

Some research findings indicate gender differences, and others indicate none in as far as the performances of men and women are concerned. One body of research maintains that there are no significant differences in the behaviors (e.g. performance ratings) of male and female leaders (Vilkinas \& Cartan, 1993), and in the overall emotional intelligence of men and women (Petrides \& Furnham, 2006). Additional studies reported that women and men in leadership roles were more similar than different (Lyness \& Thompson, 1997).

A contrasting body of research found that there are gender differences in leadership behaviors. Previous studies on entrepreneurship have shown that men and women differ in their managerial skills and performance (Perry, 2002; Morris et al., 2006). Women leaders have been reported to have better people skills than men (Rutherford, 2001), to be more visionary (Vinnicombe, 1987), to have a more democratic leadership style (Eagly \& Johnson, 1990) and a more transformational style relying on consideration and interpersonal skills (Bass \& Aviolo, 1997; Eagly and Johannesen-Schmidt, 2001). In addition, the findings of Millmore et al. (2007) illustrated that females had an overall higher performance rating score than males. On the other hand, results of Al-Ahmadi (2009) indicated that self-reported performance was significantly higher among male than female respondents. In 
another study, male leaders were assessed as more successful even when the male and female leaders demonstrated an equivalent level of competencies (Hopkins \& Bilimoria, 2008).

\subsection{Organizational Commitment and Job Performance}

There is a genuine belief that societal commitment to work is often associated with economic development and competitiveness. Highly committed employees will put forth substantial effort towards the achievement of organizational objectives and be less likely to turnover. Such employees, who describe high levels of job involvement, might reciprocate in the form of greater affective commitment to the organization, leading to increased in-role performance and citizenship behavior. The positive relationship between organizational commitment and performance indicates that increased loyalty leads individuals to exert more effort at work and increases productivity and performance. Interest in the relationship between organizational commitment and performance is also based on the assumption that employees who feel attached to, and identify with their organizations, work harder, have low rates of absenteeism and turnover, and hence have outstanding job performance. A common agreement is that highly committed employees are more motivated to work hard on their organization's behalf, and contribute more to the performance of the organization than the less committed ones.

A number of previous researchers have concurred with the findings of this study. Organizations are intended to have more highly committed workforce, because several research results show that organizational commitment leads to important outcomes such as decreased turnover, higher motivation, higher organization citizenship behavior and organizational support (e.g. Kwon \& Banks, 2004). Similarly, job performance was found to be positively and significantly correlated with overall organizational commitment (Tang et al., 2000; Suliman, 2002; Chen et al., 2006; Al-Ahmadi, 2009; Tumwebaze, 2009); affective commitment (Suliman \& Iles, 2000; Suliman, 2002; Luchak \& Gellatly, 2007; Liu, 2009); and normative commitment (Suliman \& Iles, 2000). Other results indicated that all organizational commitment subscales (affective, normative, and continuance) had a significant impact on work performance dimensions, contextual and task performance (Al Zefeiti and Mohamad, 2017). Greater organizational commitment has been linked to low rates of absenteeism and also better job performance.

On the other hand, very few researchers have found no significant relationships between commitment and performance (Yiing \& Ahmad, 2009; Pinho et al, 2014). Carmeli and Freund (2004) found out that performance was not significantly related to affective and continuance commitments. Continuance commitment tends to be unrelated or negatively correlated to work behaviors such as attendance, job performance and organizational citizenship behavior (Suliman, 2002; Meyer et al., 2002).

\section{Conclusion and Recommendation}

The demographic variable of gender is generally a weak predictor of work attitudes and performance. Job performance is positively and significantly related to the work attitude of organizational commitment. Employees who value hard work, and are committed and highly participate in organizational activities are likely to be outstanding (good) performers. The study findings are in agreement with the commitment-performance model (Steers, 1977; Putterill \& Rohrer, 1995) which asserts that there are linkages between job performance outcomes and antecedent conditions, both experiences and behaviors, aiming thereby at any time to reflect the prevailing state of employee commitment. In this model, organizational commitment, as a work attitude, intermediates experience and behavior in influencing individual job performance. However, targeting one employee attitude in order to improve performance may not be enough. It is very important to focus on a combined pattern of work attitudes to obtain the desired goals. Human resource managers should, in addition to recruiting and selecting competent employees (quality at the gate), focus on improving employee work attitudes so that appropriate individual decision making processes (that are in line with organizational goals) take place.

\section{Limitations}

Data were in the first place collected by a self-administered questionnaire, a method with some shortcomings (e.g. a bias of general method variance, and social desirability effects), and the validity of the results may not be very high. Nevertheless, the use of validated and usable measures reduced the possibility of bias in general method variance. Second, the performance measure was based on self-evaluation and may have caused over-rating of performance scores. Third, the sample was restricted to one category of respondents: the sub-county chiefs. Consequently, the findings may not be generalized to other sectors or to other national and cultural contexts. In order to overcome these limitations, similar research is recommended using alternative performance measures, drawing on a more diverse sample and which explores the relevance, if any, of national culture.

\section{References}

Abboushi, S. (1990). Impact of individual variables on the work values of Palestinian Arabs. International Studies of Management and Organization, 20(3), 53-68.

Adanu, T. S. A. (2007). Continuing professional development in state-owned university libraries in Ghana. Library 
Management, 28(6/7), 292-305.

Adeyemi-Bello, T. (1994). Work values of males and females: A developing country's example. International Journal of Management, 11(4), 940-5.

Afshari, L. and Gibson, P. (2016), "How to increase organizational commitment through transactional leadership", Leadership \& Organization Development Journal, Vol. 37 No. 4, pp. 507-519.

Al Zefeiti, S. M. B., and Mohamad, N. A (2017), The Influence of Organizational Commitment on Omani Public Employees' Work Performance, International Review of Management and Marketing, 7(2), 151-160.

Al-Ahmadi, H. (2009). Factors affecting performance of hospital nurses in Riyadh Region, Saudi Arabia. International Journal of Health Care Quality Assurance, 22(1), 40-54.

Allen, N. J., \& Meyer, J. P. (1990). The measurement and antecedents of affective, continuance and normative commitment to the organization. Journal of Occupational Psychology, 63, 1-18.

Alsos, G. A., Isaksen, E. J., \& Ljunggren, E. (2006). New venture financing and subsequent business growth in men- and women-led businesses. Entrepreneurship Theory \& Practice, 30(5), 667-88.

Angle, H. L., \& Lawson, M. B. (1994). Organizational commitment and employees performance ratings: Both type of commitment and performance count. Psychological Reports, 75, 1539-51.

Arinaitwe, J. (2005). Competence, empowerment, commitment, organizational social capital and OCB. Unpublished master's thesis, Makerere University Institute of Psychology, Kampala, Uganda.

Aven, F., Parker, B., \& McEvoy, G. (1993). Gender and attitudinal commitment to organizations: A meta-analysis. Journal of Business Research, 26, 49-73.

Bass, B. M., \& Aviolo, B. J. (1997). Shatter the glass ceiling: Women may make better managers. Oxford University Press, New York, NY.

Bhide, A. V. (2000). The origin and evolution of new businesses. Oxford University Press, New York, NY.

Boyatzis, R. E. (1982). The competent manager: A model for effective performance. John Wiley \& Sons, New York, NY.

Brenner, O. C., Tomkiewicz, J., \& Schein, V.E. (1989). The relationship between sex role stereotypes and requisite management characteristics revisited. Academy of Management Journal, 32, 662-9.

Bruni, A., Gherardi, S., \& Poggio, B. (2004). Entrepreneur-mentality, gender and the study of women entrepreneurs. Journal of Organizational Change Management, 17(3), 256-68.

Brush, C., Carter, N., Gatewood, E., Greene, P., \& Hart, M. (2004). Clearing the hurdles: women building highgrowth enterprises. Financial Times/Prentice-Hall, New York, NY.

Carmeli, A. (2005). Exploring determinants of job involvement: an empirical test among senior executives. International Journal of Manpower, 26(5), 457-472.

Carmeli, A., \& Freund, A. (2004). Work commitment, job satisfaction, and job performance: An empirical investigation. International Journal of Organization Theory and Behavior, 7(3), 289-309.

Carriere, J., \& Bourque, C. (2009). The effects of organizational communication on job satisfaction and organizational commitment in a land ambulance service and the mediating role of communication satisfaction. Career Development International, 14(1), 29-49.

Caruana, A., Ewing, M., \& Ramaseshan, B. (1997). Organizational commitment and performance: The Australian public sector experience. School Research Series, School of Marketing, Curtin University, Perth.

Cassar, G. (2004). Entrepreneur opportunity costs and intended venture growth. Journal of Business Venturing, 21(5), 610-32.

Chen, J., Silverthorne, C., \& Hung, J. (2006). Organization communication, job stress, organizational commitment, and job performance of accounting professionals in Taiwan and America. Leadership \& Organization Development Journal, 27(4), 242-249.

Cohen, A. (1992). Antecedents of organizational commitment across occupational groups: A meta-analysis. Journal of Organizational Behavior, 13(6), 539-59.

Covin, J. G., Green, K. M., \& Slevin, D. P. (2006). Strategic process effects on the entrepreneurial orientationsales growth rate relationship. Entrepreneurship Theory and Practice, 30(1), 57-81.

Crossman, A., \& Abou-Zaki, B. (2003). Job satisfaction and employee performance of Lebanese banking staff. Journal of Managerial Psychology, 18(4), 368-76.

Dafna, K. (2008). Managerial performance and business success: Gender differences in Canadian and Israeli entrepreneurs. Journal of Enterprising Communities: People and Places in the Global Economy, 2(4), 300331.

Dick, G., \& Metcalfe, B. (2007). The progress of female police officers? An empirical analysis of organizational commitment and tenure explanations in two UK police forces. International Journal of Public Sector Management, 20(2), 81-100.

Dipboye, R. L., Smith, C. S., \& Howell, W. C. (1994). Understanding an industrial and integrated organizational approach psychology. Harcourt Brace College Publishers, FortWorth, TX.

Dixon, M. A., Cunningham, G. B., Sagas, M., Turner, B. A., \& Kent, A. (2005). Challenge is key: An investigation 
of affective organizational commitment in undergraduate interns. Journal of Education for Business, January/February, 172-80.

Dodd-McCue, D., \& Wright, G. (1996). Men, women, and attitudinal commitment: the effects of workplace experiences and socialization. Human Relations, 49, 1065-91.

Du Reitz, A., \& Henrekson, M. (2000). Testing the female underperformance hypothesis. Small Business Economics, 14, 1-10.

Eagly, A. H., \& Johannesen-Schmidt, M. C. (2001). The leadership styles of women and men. Journal of Social Issues, 57, 781-97.

Eagly, A. H., \& Johnson, B. T. (1990). Gender and leadership style: A meta-analysis. Psychological Bulletin, 108, 233-56.

Eagly, A. H., Wood, W., \& Diekman, A.B. (2000). Social role theory of sex differences and similarities: A current appraisal. In T. Eckes. \& H. M. Trautner (Eds), The developmental social psychology of gender. Lawrence Earlbaum Associates, Mahwah, NJ.

El Badawy, T. A., Chinta, R., Magdy, M, M (2018) "Does 'gender' mediate or moderate the relationship between 'quality of work life' and 'organizational commitment'?: Evidence from SMEs in Egypt", Gender in Management: An International Journal, https://doi.org/10.1108/GM-04-2017-0050

Fletcher, C. (1999). The implication of research on gender differences in self-assessment and 360 degree appraisal. Human Resource Management Journal, 9(1), 39-46.

Fogarty, T. (1996), "Gender differences in the perception of the work environment within large international accounting firms", Managerial Auditing Journal, Vol. $11 \quad$ No. 2, pp. 1019. https://doi.org/10.1108/02686909610107924

Freund, A., \& Carmeli, A. (2003). An empirical assessment: Reconstructed model for five universal forms of work commitment. Journal of Managerial Psychology, 18(7), 708-725.

Gava, S. N. (2005). Operant competence, explicit knowledge, role clarity, empowerment, commitment and OCBS of information technology analysts. Unpublished master's thesis, Makerere University Institute of Psychology, Kampala, Uganda.

Goldsmith, R. E., Freiden, J. B., \& Eastman, J. K. (1995). The generality/specificity issue in consumer innovativeness research. Technovation, 15(10), 601-12.

Gray, J. (1992), Men Are from Mars, Women Are from Venus, Harper Collins Publishers, New York, NY.

Greener, I. (2007). The politics of gender in the NHS: Impression management and getting things done. Gender, Work \& Organization, 14(3), 281-99.

Grilo, I., \& Irigoyen, J.M. (2006). Entrepreneurship in the EU: To wish and not to be. Small Business Economics, 26(4), 305-18.

Hailesilasie, G. (2009). Determinants of public employees' performance: Evidence from Ethiopian public organizations. International Journal of Productivity and Performance Management, 58(3), 238-253.

Heilman, M., Block, C. J., \& Martell, R. F. (1995). Sex stereotypes: Do they influence perceptions of managers? Journal of Social Behavior and Personality, 10, 237-52.

Heilman, M., Martell, R., \& Simon, M. (1988). The vagaries of sex bias: Conditions regulating the undervaluation, equivaluation and overvaluation of female job applicants. Organizational Behaviour and Human Decision Processes, 41(1), 98-110.

Hendri, M. I (2019), The mediation effect of job satisfaction and organizational commitment on the organizational learning effect of the employee performance, International Journal of Productivity and Performance Management Vol. 68 No. 7, pp. 1208-1234

Hopkins, M. M., \& Bilimoria, D. (2008). Social and emotional competencies predicting success for male and female executives. Journal of Management Development, 27(1), 13- 35.

Hunt, S. D., Chonko, L. B., \& Wood, V. R. (1985). Organizational commitment and marketing. Journal of

Marketing, 49, 112-26.

Indarti, S., Solimun., Fernandes, A. A. R., and Hakim, W. (2017), The effect of OCB in relationship between personality, organizational commitment and job satisfaction on performance, Journal of Management Development Vol. 36 No. 10, pp. 1283-1293.

Johnsen, G. J., \& McMahon, R. G. P. (2005). Owner-manager gender, financial performance and business growth amongst SMEs from Australia's business longitudinal survey. International Small Business Journal, 23(2), 115-40.

Joiner, T. A., \& Bakalis, S. (2006). The antecedents of organizational commitment: The case of Australian casual academics. International Journal of Educational Management, 20(6), 439-452.

Kaldenberg, D., Becker, B., \& Zvonkovic, A. (1995). Work and commitment among young professionals: A study of male and female dentists. Human Relations, 48(11), 135577.

Khatri, N., \& Fern, C. T. (2001). Explaining employee turnover in an Asia context. Human Resource Management Journal, 11(1), 54-74. 
Kim, H., Lee, U. and Kim, Y. (2015), "The effect of workplace diversity management in a highly male-dominated culture", Career Development International, Vol. 20 No. 3, pp. 259-272. https://doi.org/10.1108/CDI-062014-0082.

Kolovich, S. (2015), "Mustaches outnumber women among medical-school leaders", The Chronicle of Higher Education, available at: http://chronicle.com/article/Mustaches-Outnumber-Women/ 234645 (accessed 28 April 2017).

Kuruuzum, A., Cetin. E. I., \& Irmak, S. (2009). Path analysis of organizational commitment, job involvement and job satisfaction in Turkish hospitality industry. Tourism Review, 64(1), 4-16.

Kwon, I. G., \& Banks, D. W. (2004). Factors related to the organizational and professional commitment of internal auditors. Managerial Auditing Journal, 19(5), 606-22.

Labatmediene, L., Endriulaitiene, A., \& Gustainiene, L. (2007). Individual correlates of organizational commitment and intention to leave the organization. Baltic Journal of Management, 2(2), 196-212.

Liu, Y. (2009). Perceived organizational support and expatriate organizational citizenship behavior: The mediating role of affective commitment towards the parent company. Personnel Review, 38(3), 307-319.

Low, M. B., \& MacMillan, I. C. (1988). Entrepreneurship: Past research and future challenges. Journal of Management, 14(2), 139-61.

Luchak, A. A., \& Gellatly, I. R. (2007). Comparison of linear and nonlinear relations between organizational commitment and work outcomes. Journal of Applied Psychology, 92(3), 786-93.

Lyness, K. S., \& Thompson, D. E. (1997). Above the glass ceiling? A comparison of matched samples of female and male executives. Journal of Applied Psychology, 82, 359-75.

Maamari, B. E., and Saheb, A (2018). How organizational culture and leadership style affect employees' performance of genders, International Journal of Organizational Analysis Vol. 26 No. 4, 2018 pp. 630-651

Marchiori, D. M., \& Henkin, A. B. (2004). Organizational commitment of a health profession faculty: Dimensions correlated and conditions. Medical Teacher, 26(4), 353-8.

Martell, R. F., \& De Smet, A. L. (2001). A diagnostic-ratio approach to measuring beliefs about the leadership abilities of male and female managers. Journal of Applied Psychology, 86, 1223-31.

Matagi, L. (2006). Gender-friendly human resource management and organizational commitment: A study of organizations in Uganda. In OSSREA Gender Issues Research Report Series, 23, 123-157. Addis Ababa, Ethiopia.

Mathieu, J. E., \& Zajac, D. M. (1990). A review and meta-analysis of the antecedents, correlates, and consequences of organisational commitment. Psychological Bulletin, 108, 171-94.

Matsiko, E. (2005). Competences, leadership styles, commitment and OCB among head teachers of primary schools. Unpublished master's thesis, Makerere University Institute of Psychology, Kampala, Uganda.

McCaul, H. S., Hinsz, V. B., \& McCaul, K. D. (1995). Assessing organizational commitment: An employee's global attitude towards the organization. Applied Behavioral Science, 1, 80-90.

Menzies, T. V., Diochon, M., \& Gasse, Y. (2004). Examining venture-related myths concerning women entrepreneurs. Journal of Developmental Entrepreneurship, 9(2), 89-108.

Merrill-Sands, D. M., \& Kolb, D. M. (2001). Women as leaders: The paradox of success. Center for Gender in Organizations' Insights, Briefing Note 9, Apri, 1-4

Metcalfe, B. and Dick, G. (2002), "Is the force still with her? Gender and commitment in the police", Women in Management Review, Vol. 17 No. 8, pp. 392-403. https://doi.org/10.1108/09649420210451823

Metcalfe, B., \& Altman, Y. (2001). Leadership. In E. Wilson (Ed.), Organizational Behaviour Reassessed: The Impact of Gender. Sage Publications, London.

Meyer, J. P., \& Allen, N. J. (1991). A three component conceptualization of organizational commitment. Human Resource Management Review, 1, 61-89.

Meyer, J. P., \& Allen, N. J. (1997). Commitment in the Workplace: Theory, Research and Application. Sage Publication, Newbury Park: ATOB, Thousand Oaks, CA.

Meyer, J. P., Allen, N. J., \& Gellatly, I.R. (1990). Affective and continuance commitment to the organization: Evaluation of measures and analysis of concurrent and time-lagged relations. Journal of Applied Psychology, 6, 710-20.

Meyer, J. P., Paunonen, S. V., Gellatly, I. R., Goffin, R. D., \& Jackson, D. N. (1989). Organizational commitment and job performance: It's the nature of the commitment that counts. Journal of Applied Psychology, 74(1), $152-6$.

Meyer, J. P., Stanley, D. J., Herscovitch, L., \& Topolnytsky, L. (2002). Affective, continuance, and normative commitment to the organization: A meta-analysis of antecedents, correlates, and consequences. Journal of Vocational Behavior, 61(1), 20-52.

Millmore, M., Biggs, D., \& Morse, L. (2007). Gender differences within 360-degree managerial performance appraisals. Women in Management Review, 22(7), 536-551.

Morris, M. H., Miyasaki, N. N., Watters, C. E., \& Coombes, S. M. (2006). The dilemma of growth: Understanding 
venture size choices of women entrepreneurs. Journal of Small Business Management, 44(2), 221-44.

Mowday, R. T., Steers, R. M., \& Porter, L. W. (1979). The measurement of organizational commitment. Journal of Vocational Behavior, 14, 224-27.

Mowday, R., Porter, L., \& Steers, R (1982), Employee-organisation Linkages: The Psychology of Commitment and Absenteeism and Turnover. Academic Press, New York, NY.

Namasivayam, K., \& Zhao, X. (2007). An investigation of the moderating effects of organizational commitment on the relationships between work-family conflict and job satisfaction among hospitality employees in India. Tourism Management, 28, 1212-1223.

Nasab, A. H., and Afshari, L (2019). Authentic leadership and employee performance: Mediating role of organizational commitment, Leadership and Organization Development Journal Vol. 40 No. 5, 2019 pp. 548 560 .

Ngo, H., \& Tsang, W. (1998). Employment practices and organizational commitment: Differential effects for men and women? International Journal of Organizational Analysis, 6(3), 251-66.

Orser, B. J., \& Riding, A. L. (2004). Exporting as a means of growth for women-owned Canadian SMEs. Journal of Small Business and Entrepreneurship, 17(3), 153-74.

Perrault, M. R., \& Irwin, J. K. (1996). Gender differences at work: are men and women really that different? Advanced Teamwares Inc., Agoura Hills, CA.

Perry, S. C. (2002). A comparison of failed and non-failed small businesses in the United States: Do men and women use different planning and decision making strategies? Journal of Developmental Entrepreneurship, 7, 415-28.

Peterson, M., Kara, A., Fanimokun, A. and Smith, P. (2019), "Country culture moderators of the relationship between gender and organizational commitment", Baltic Journal of Management, Vol. 14 No. 3, pp. 389410. https://doi.org/10.1108/BJM-04-2018-0143.

Petrides, K. V., \& Furnham, A. (2006). The role of trait emotional intelligence in a gender specific model of organizational variables. Journal of Applied Social Psychology, 36, 552-69.

Pinho, J. C., Rodrigues, A. P., and Dibb, S (2014), The role of corporate culture, market orientation and organisational commitment in organisational performance The case of non-profit organisations, Journal of Management Development Vol. 33 No. 4, 2014 pp. 374-398.

Popoola, S. and Oluwole, D. (2007), "Career commitment among records management personnel in a State Civil Service in Nigeria", Records Management Journal, Vol. 17 No. 2, pp. 107 116. https://doi.org/10.1108/09565690710757904.

Putterill, M. S., \& Rohrer, T. C. (1995). A causal model of employee commitment in a manufacturing setting. International Journal of Manpower, 16(5/6), 56-69.

Rodríguez-Ruiz, O., Rodríguez-Duarte, A and Gómez-Martínez, L (2016). Does a balanced gender ratio improve performance? The case of Spanish banks (1999-2010), Personnel Review Vol. 45 No. 1, pp. 103-120.

Rosener, J. (1990). Ways women lead. Harvard Business Review, November/December, 120-5.

Rukh, L., Shahrukh, H.M. and Iqbal, K.Z. (2018), "Effect of authentic leadership on organization commitment: mediating role of job satisfaction", Journal of Entrepreneurship \& Organization Management, Vol. 7 No. 3 , pp. 247-248.

Rutherford, S. (2001). Any difference? An analysis of gender and divisional management styles in a large airline. Gender, Work and Organization, 8, 326-45.

Sackett, P, R. (2002). The structure of counterproductive work behaviors: Dimensionality and relationships with facets of job performance. International Journal of Selection and Assessment, 10(1/2), 5-11.

Samad, S. (2005). Unraveling the organizational commitment and job performance relationship. The Business Review, 4(2), 79-84.

Sandberg, S. (2013), Lean in: Women, Work and the Will to Lead, Alfred Knof Publishing, a division of Random House, New York, NY.

Sande, J. H. (2005). Competence-based training, role clarity, organizational commitment, levels of stress and OCB among HIV/AIDS counselors. Unpublished master's thesis, Makerere University Institute of Psychology, Kampala, Uganda.

Schwartz, F. (1989). Management women and the new facts life. Harvard Business Review, 67, 65-76.

Sethivikram, V., Meinert, D., Kingrking, R., \& Sethiavsethi, V. (1996). The Multi-dimensional nature of organizational commitment among information systems personnel. Second Americas Conference on Information Systems, Phoenix, AZ, August 16-18, 1-4.

Sexton, D. L., \& Bowman-Upton, N. (1990). Female and male entrepreneurs: Psychological characteristics and their role in gender related discrimination. Journal of Business Venturing, 5(1), 29-36.

Sezgin, F. (2009). Relationship between teacher organisatinal commitment, psychological hardiness and some demographic variables in Turkish primary schools. Journal of Educational Administration, 47(5), 630-651.

Sharpe, R. (2000). As leaders, women rule. Business Week, November 20, 74-84. 
Shore, T. H. (1992). Subtle gender bias in the assessment of managerial potential. Sex Roles, 27, 499-515.

Singh, P., Finn, D., \& Goulet, L. (2004). Gender and job attitudes: A re-examination and extension. Women in Management Review, 19(7), 345-355.

Slaughter, A. (2015), Unfinished Business: Women, Men, Work, Family, Random House Inc, New York, NY.

Smith, P., Smits, S., \& Hoy, F. (1998). Employee work attitudes: The subtle influence of gender. Human Relations, $51,649-66$

Solakoglu, M, N., and Demir, N (2016). The role of firm characteristics on the relationship between gender diversity and firm performance, Management Decision, vol. 54 no. 6.

Steers, M. (1977). Antecedents and outcomes of organizational commitment. Administrative Science Quarterly, $22,46-56$.

Subramaniam, N., McManus, L., \& Mia, L. (2002). Enhancing hotel managers' organizational commitment: An investigation of the impact of structure, need for achievement and participative budgeting. International Journal of Hospitality Management, 21(4), 303-20.

Suliman, A and Al Kathairi, M. (2013), Organizational justice, commitment and performance in developing countries: The case of the UAE, Employee Relations Vol. 35 No. 1, 2013 pp. 98-115.

Suliman, A. M. T. (2002). Is it really a mediating construct? The mediating role of organizational commitment in work climate-performance relationship. Journal of Management Development, 21(3), 170-183.

Suliman, A. M. T. (2007). Links between justice, satisfaction and performance in the workplace: A survey in the UAE and Arabic context. Journal of Management Development, 26(4), 294-311.

Suliman, A., \& Iles. P. (2000). Is continuance commitment beneficial to organizations? Commitment-performance relationship: A new look. Journal of Managerial Psychology, 15(5), 407-426.

Tang, T. L. P., Singer, M. G., \& Roberts, S. (2000). Employees' perceived organizational instrumentality: An examination of the gender differences. Journal of Managerial Psychology, 15(5), 378-406.

Torlak, N. G., Kuzey, C., and Ragom, M. (2018), Human resource management, commitment and performance links in Iran and Turkey, International Journal of Productivity and Performance Management Vol. 67 No. 9 , 2018 pp. 1994-2017.

Tumwebaze, C. (2009). An exploratory study into secondary school teacher motivation, occupational attitudes and job performance in Uganda in the context of HIV/AIDS. Unpublished doctoral dissertation, Trinity College, University of Dublin, Ireland.

Vandenberg, R. J., \& Scarpello, V. (1994). A longitudinal assessment of the determinant relationship between employee commitments to the occupation and the organization. Journal of Organizational Behavior, 15, 535-47.

Vilkinas, T., \& Cartan, G. (1993). Competencies of Australian women in management. Women in Management Review, 8, 31-5.

Vinnicombe, S. (1987). What exactly are the differences in male and female working styles? Women in Management Review, 3, 13-21.

Wahn, J. C. (1998). Sex differences in the continuance component of organizational commitment. Group and Organization Management, 23(3), 256-67.

Walker, E., \& Webster, B. (2006). Management competencies of women business owners. The International Entrepreneurship and Management Journal, 2(4), 495-508.

Ward, E. A., \& Davis, E. (1995). The effect of benefit satisfaction on organization commitment. Compensation \& Benefits Management, 11(3), 35-40.

Watson, J. (2006). External funding and firm growth: Comparing female- and male-controlled SMEs. Venture Capital, 8(1), 33-49.

Yiing, L. H., \& Ahmad, K. Z. B. (2009). The moderating effects of organizational culture on the relationships between leadership behaviour and organizational commitment and between organizational commitment and job satisfaction and performance. Leadership and Organization Development Journal, 30(1), 53-86.

Yilmaz, C. (2002). Salesperson performance and job attitudes revised: An extended model and effects of potential moderators. European Journal of Marketing, 36(11/12), 1389-1414.

Yousef, D. A. (2000). Organizational commitment: A mediator of the relationships of leadership behaviour with job satisfaction and performance in a non-western country. Journal of Managerial Psychology, 15(1), 6-28.

Yousef, D. A. (2001). Islamic work ethic: A moderator between organizational commitment and job satisfaction in a cross-cultural context. Personnel Review, 30(2), 152-169. 